\title{
Pathogenicity of Macrophomina phaseolina to Mature Plant Tissues of Alfalfa and White Clover
}

\author{
R. G. Pratt, M. R. McLaughlin, G. A. Pederson, and D. E. Rowe, USDA-ARS, Waste Management and Forage \\ Research Unit, Mississippi State, MS 39762
}

\begin{abstract}
Pratt, R. G., McLaughlin, M. R., Pederson, G. A., and Rowe, D. E. 1998. Pathogenicity of Macrophomina phaseolina to mature plant tissues of alfalfa and white clover. Plant Dis. 82:1033-1038.

Macrophomina phaseolina has been observed on alfalfa and white clover in North America, but its pathogenicity to mature plants of these species has not been adequately documented and Koch's postulates have not been fulfilled. Isolates of M. phaseolina from alfalfa and white clover were evaluated for pathogenicity by inoculating tissues of mature plants with infested toothpick pieces. Excised leaf tissues also were inoculated with mycelium. In stolons of white clover and stems of alfalfa, M. phaseolina caused a brown-black, basipetally progressive necrosis of vascular tissue with subsequent collapse of the surrounding pith and epidermis to produce radially constricted, expanding lesions. In taproots and crowns of alfalfa, M. phaseolina caused dark discoloration of vascular tissues in bands or streaks above and below inoculation points with subsequent invasion and death of cortical tissues, lateral roots, and stems. Sclerotia formed in all tissues of both species. Excised leaf tissues were rapidly parasitized, but significant differences in rates of parasitism between genotypes suggested that differences in host resistance to M. phaseolina may be present in both species. Pycnidia formed on leaves of bean, lima bean, and cotton. All isolates of M. phaseolina were reisolated from margins of necrosis in all types of inoculated tissues and regrown in pure culture. These results fulfill Koch's postulates for $M$. phaseolina as a pathogen of mature white clover and alfalfa in North America, and they demonstrate its capacity to parasitize a variety of tissues of both species in the absence of other pathogens. Results indicate that $M$. phaseolina should be considered a potential cause for lack of persistence of white clover and alfalfa during summer months in the southeastern United States.
\end{abstract}

Macrophomina phaseolina (Tassi) Goidanich is a pathogen with an exceptionally broad host range that includes over 500 species of monocots and dicots (34). Diseases incited by $M$. phaseolina are often referred to as "charcoal rot" because of a dark coloration imparted to parasitized host tissue. On several agronomic crops in North America, M. phaseolina is a major pathogen that may cause significant economic losses under conditions favorable for disease $(2,26,34)$.

M. phaseolina is primarily a soilborne, root-infecting organism that causes damage by plugging or rotting of vascular tissue in roots and lower stems or stalks $(26,34)$. Disease incidence and severity are often

\section{Corresponding author: R. G. Pratt}

Mention of a trademark or proprietary product does not constitute an endorsement or warranty of the product by the United States Department of Agriculture and does not imply its approval to the exclusion of other products that may also be suitable.

Accepted for publication 10 June 1998.

Publication no. D-1998-0720-03R

This article is in the public domain and not copyrightable. It may be freely reprinted with customary crediting of the source. The American Phytopathological Society, 1998. greatest when maturing plants are stressed by drought and high temperature $(4,22,34)$. Sclerotia produced in parasitized host tissue function as units of long-term survival in soil and primary inoculum for root infection (26,29). M. phaseolina also forms pycnidia and conidia on certain hosts (33), which may enable potential aerial and seed-borne transmission.

M. phaseolina traditionally has been regarded as an opportunistic pathogen that attacks most cultivars of highly susceptible hosts under conditions that predispose for severe disease. Predisposing environmental conditions and host factors include high temperatures, dry soils and drought stress, and early flowering and senescence of host tissues $(4,22,26,34)$. Until recently, independent genes for resistance to $M$. phaseolina, apart from tolerance to the predisposing conditions, were unavailable, poorly known, or considered relatively unimportant in most crops $(20,26)$. In recent years, however, new studies have demonstrated the occurrence of genes for resistance to $M$. phaseolina in cultivars or populations of bean, castor bean, soybean, and sorghum that are independent of tolerance to predisposing conditions $(10,23,30,32)$. Breeding for specific resistance to $M$. phaseolina, therefore, may provide additional means of disease control for these crops in the future.
In North America, M. phaseolina has been reported occasionally from alfalfa (Medicago sativa L., 3,5,9,31) and more frequently from white clover (Trifolium repens L.; 5,6,12,15,19,21). However, no detailed reports have fulfilled Koch's postulates or otherwise demonstrated pathogenicity of North American isolates of Macrophomina phaseolina to mature plants of alfalfa or white clover. Therefore, the extent to which $M$. phaseolina is likely to be an important pathogen of these species can only be surmised. In the most recent Compendium of Alfalfa Diseases (31), $M$. phaseolina was listed with fungi that had been associated with the crop but for which little or no information was available on pathogenicity, distribution, and importance. In Hungary, alfalfa artificially inoculated in field plots was described as highly susceptible to M. phaseolina (14).

In the southeastern United States, high frequencies of mortality often occur in mature plants of white clover and alfalfa during late summer months (R. G. Pratt, unpublished; $1,6,7,9,11,12,21)$. Sclerotia of M. phaseolina often are present in diseased roots and stems of both species; however, signs and symptoms of numerous other potential pathogens, including Sclerotium rolfsii and species of Colletotrichum, Curvularia, Phoma, Fusarium, Leptodiscus, Rhizoctonia, Cercospora, and Nigrospora often are present in the same host tissues (R. G. Pratt, unpublished 6,7,11,12,21). Therefore, the extent to which $M$. phaseolina is a major individual pathogen of white clover and alfalfa, with a capacity to kill mature plants in the absence of other pathogens, is not clear on the basis of signs and symptoms alone.

This study was undertaken to evaluate the pathogenicity of isolates of M. phaseolina from alfalfa and white clover to stems and leaves of mature plants of white clover, and to stems, leaves, roots, and crowns of mature plants of alfalfa.

\section{MATERIALS AND METHODS}

Isolation, identification, and storage of M. phaseolina. Two isolates from white clover were obtained from field-grown plants in a previous study (27). Two alfalfa isolates were obtained from dead fieldgrown plants at Brooksville, Mississippi, in 1996. Sclerotia from dried, symptomatic root and crown tissues were placed on Difco cornmeal agar (CMA). Colonies from germinated sclerotia were transferred 
after 2 to 3 days. Isolates were identified by the morphology of sclerotia $(24-26,34)$ on CMA and potato dextrose agar (PDA), and of pycnidia and conidia produced on excised leaf tissues $(24,33,34)$. All isolates were stored on CMA in plates sealed with Parafilm for up to 1 year at $10^{\circ} \mathrm{C}$ or for 3 to 6 months at room temperature prior to transfer.

Stem inoculations of alfalfa and white clover. Stems of alfalfa cultivar Apollo and stolons of white clover cultivar Regal were inoculated with pieces of infested toothpicks by a method modified from Edmunds (4). The tips (1.0 to $1.5 \mathrm{~cm}$ long) of 50 wooden toothpicks were autoclaved for 20 min in $250 \mathrm{ml}$ distilled water, removed, blotted, re-autoclaved in additional water to remove inhibitory substances, and autoclaved for a third time in $250 \mathrm{ml} \mathrm{20 \%} \mathrm{V-8}$ juice. Toothpick pieces then were cooled in sterile Petri plates and transferred individually to margins of colonies of $M$. phaseolina on CMA. After incubation for $24 \mathrm{~h}$, infested toothpick pieces were removed and the distal $5 \mathrm{~mm}$ were excised with a razor blade and used as inoculum.

Apices of growing stems of alfalfa 25 to $30 \mathrm{~cm}$ long, and stolons of white clover 15 to $20 \mathrm{~cm}$ long, produced on plants grown

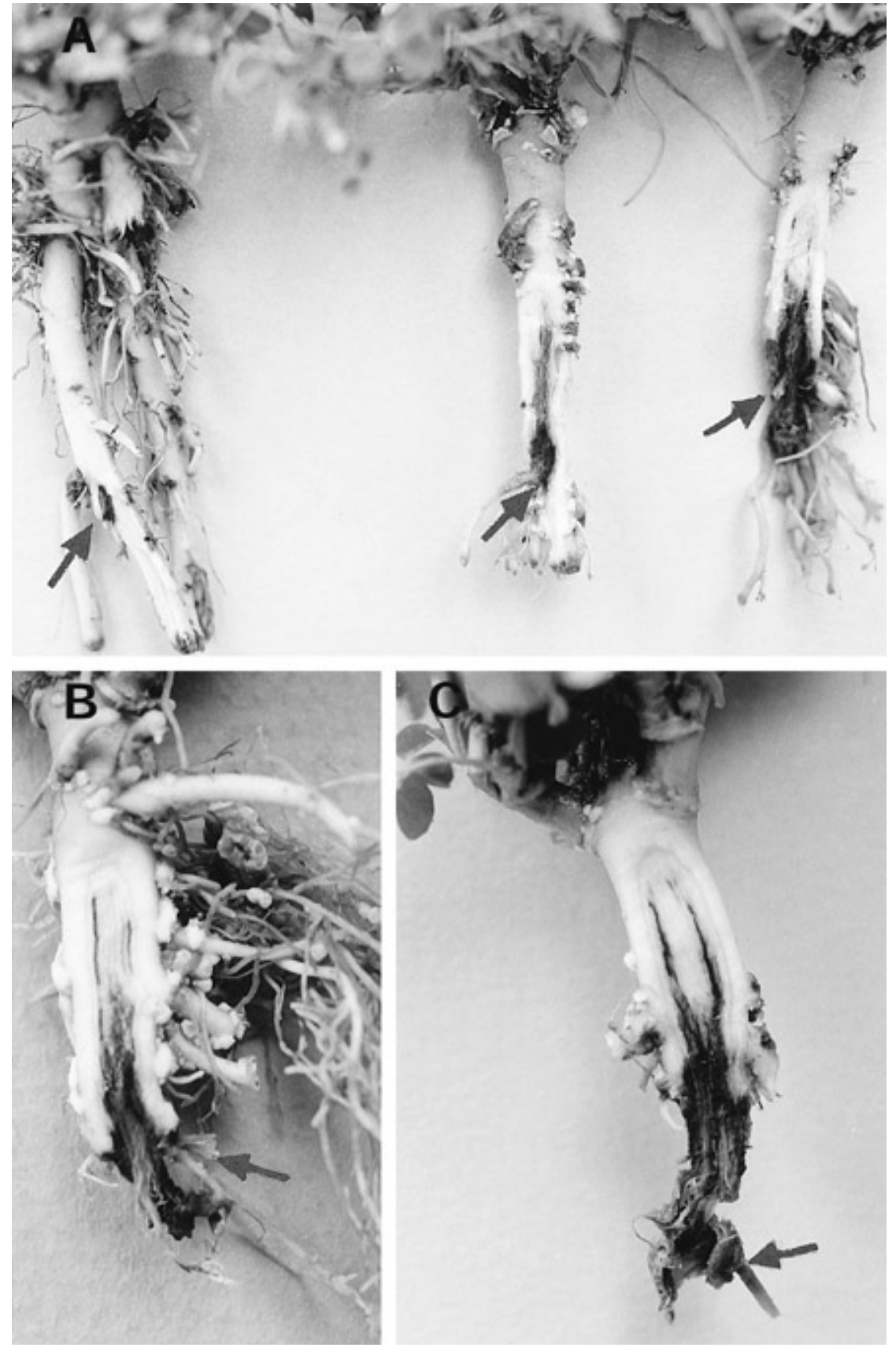

Fig. 1. Symptoms induced by Macrophomina phaseolina following inoculation of lower taproots of alfalfa. Inoculation sites are indicated by arrows. (A) Control (left plant) with slight discoloration around wound site and inoculated roots (right) with severe discoloration. (B) and (C) are close views of internal vascular discoloration and cortical rotting in inoculated roots. Toothpick piece remains on right side of rotted tip of taproot of plant in $(\mathrm{C})$. for 4 to 6 months in pots $\left(374 \mathrm{~cm}^{3}\right)$ of potting mixture (28) in the greenhouse, were excised where diameters were first large enough to insert a toothpick piece. A single toothpick piece was inserted completely into the stem or stolon, and the cut surface was sealed with petrolatum (vaseline) to prevent desiccation. After incubation for 3 weeks in ambient air $\left(21\right.$ to $\left.27^{\circ} \mathrm{C}\right)$ in the greenhouse, the length of necrosis from the tip of the toothpick piece to the constricted margin of the necrotic lesion was measured. Control inoculations were performed with toothpick pieces prepared in the same manner and incubated on noninfested CMA.

Root and crown inoculations of alfalfa. Roots of plants grown as described for stem inoculations were washed free of potting mixture. Infested toothpick pieces were inserted fully into holes made with a dissecting needle in terminal portions of taproots, parallel to the root axis, where roots were first large enough to insert toothpicks, and into holes in uppermost taproots or crowns perpendicular to the root axis. Entrance points were covered with petrolatum and plants were repotted and grown for 3 weeks (roots) or 5 to 6 weeks (crowns) in the greenhouse. Plants then were washed free of potting mixture and bisected through inoculation sites. For root inoculations, the maximum length of continuous necrosis from the toothpick toward the crown was measured. For crown inoculations, where upward symptom development was limited by stems, maximum necrosis in any direction was scored by a 5-point system, where $0=$ maximum continuous discoloration 0 to 0.2 $\mathrm{cm}$ from toothpick, $1=0.2$ to $0.5 \mathrm{~cm}, 2=0.5$ to $1 \mathrm{~cm}, 3=1$ to $1.5 \mathrm{~cm}$, and $4=>1.5 \mathrm{~cm}$.

Leaf inoculations. Excised leaf tissues of alfalfa and white clover were inoculated with $M$. phaseolina by modification of a method used for Sclerotinia trifoliorum (28). The second fully expanded leaf proximal from a growing stem or stolon tip was excised, and a disc $12 \mathrm{~mm}$ in diameter was cut with a \#6 cork borer from the terminal leaflet and placed on a small Petri plate (35-mm diameter) of water agar. A disc of agar, $6 \mathrm{~mm}$ in diameter, cut from a growing colony margin of $M$. phaseolina on CMA, was inverted on the edge of the leaf disc at the base of the midvein so that half of the agar block rested on leaf tissue and half on agar. Plates were incubated in a growth chamber at $24^{\circ} \mathrm{C}$ with combined fluorescent and incandescent lights (145 to $290 \mathrm{Em}^{-2} \mathrm{~s}^{-1}$ intensity) on a 12 -h photoperiod for 1 week. Leaves were scored inversely according to days when the disc of tissue became completely necrotic (i.e., score $6=$ necrotic at 2 days, $5=3$ days, $2=$ 6 days, and $1=7$ days). Tissues not completely necrotic at 7 days after inoculation were scored as 0.01 to 0.99 according to the proportions visibly necrotic. Tissues with no visible necrosis were scored as 0 . 
Table 1. Mean lengths of necrosis induced in stems of alfalfa and stolons of white clover following inoculation with isolates of Macrophomina phaseolina ${ }^{\mathrm{x}}$

\begin{tabular}{|c|c|c|c|c|c|}
\hline \multirow[b]{3}{*}{ Source of isolates } & \multirow[b]{3}{*}{ Isolates } & \multicolumn{4}{|c|}{ Mean length of necrosis $(\mathrm{cm})^{y}$} \\
\hline & & \multicolumn{2}{|c|}{ White clover } & \multicolumn{2}{|c|}{ Alfalfa } \\
\hline & & Exp. 1 & Exp. 2 & Exp. 1 & Exp. 2 \\
\hline & 0 & $0.48 \mathrm{a}^{\mathrm{z}}$ & $0.51 \mathrm{a}$ & $0.00 \mathrm{a}$ & $0.00 \mathrm{a}$ \\
\hline \multirow[t]{2}{*}{ White clover } & 1 & $2.25 \mathrm{~b}$ & $6.49 \mathrm{c}$ & $3.22 \mathrm{~b}$ & $6.58 \mathrm{bc}$ \\
\hline & 2 & $1.19 \mathrm{a}$ & $3.20 \mathrm{~b}$ & $3.70 \mathrm{~b}$ & $3.84 \mathrm{ab}$ \\
\hline \multirow[t]{2}{*}{ Alfalfa } & 3 & $2.55 \mathrm{~b}$ & $6.06 \mathrm{c}$ & $3.35 \mathrm{~b}$ & $6.74 \mathrm{bc}$ \\
\hline & 4 & $4.47 \mathrm{c}$ & $5.44 \mathrm{c}$ & $3.80 \mathrm{~b}$ & $10.42 \mathrm{c}$ \\
\hline
\end{tabular}

${ }^{\mathrm{x}}$ Growing stems and stolons were inoculated by inserting a small piece of infested toothpick into cut ends after tips were excised and were incubated in a greenhouse for 3 weeks. Controls ( 0 isolate $)$ received noninfested toothpick pieces.

${ }^{y}$ Mean length of necrosis measured from tip of inoculation point to margin of complete necrosis in eight replicate plants, one stem per plant, arranged in a randomized complete block design.

z Means in a column not followed by the same letter differ significantly at $P=0.05$ according to the least significant difference test.
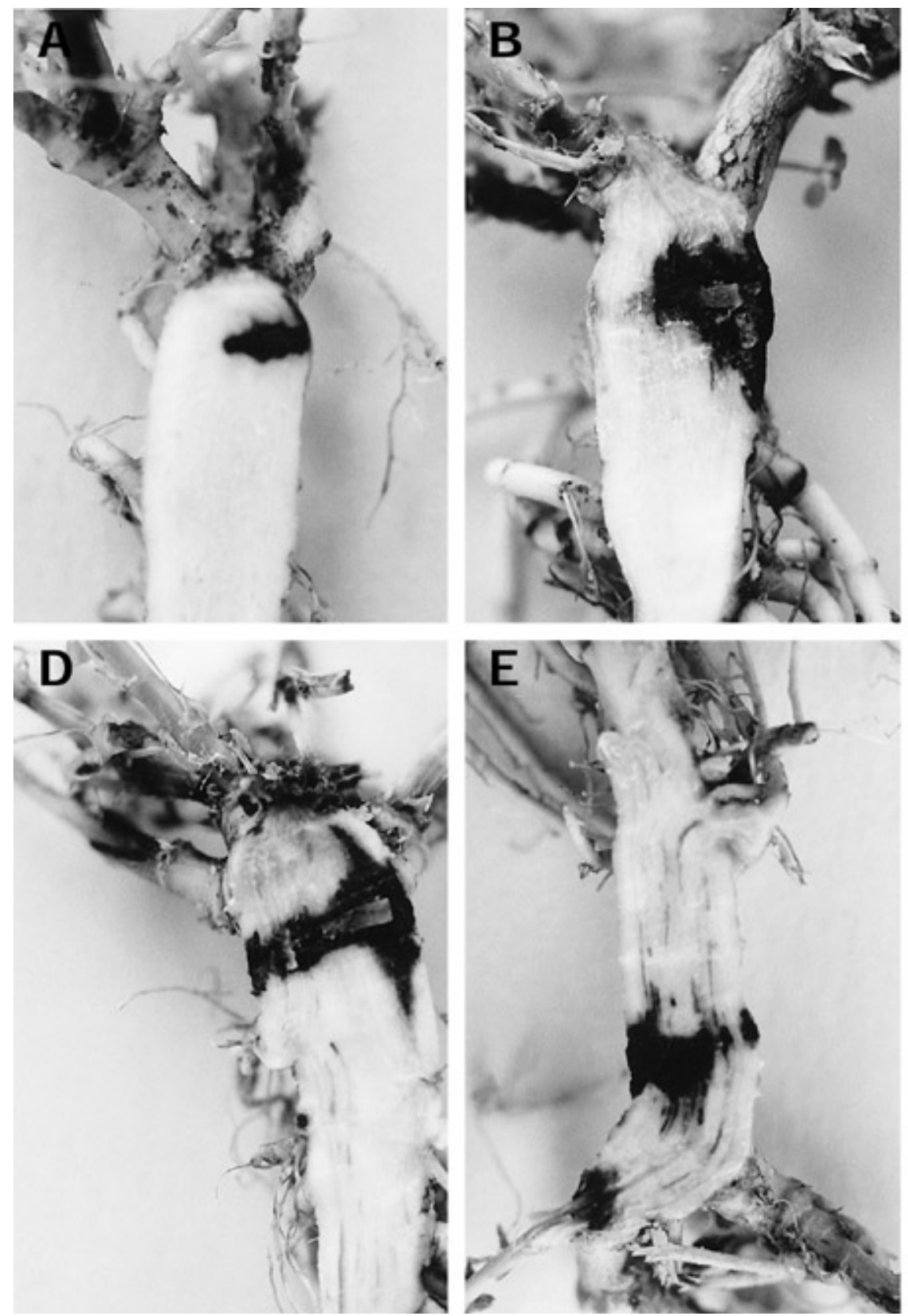

Inoculations also were performed in the same manner with leaf tissues of common bean (Phaseolus vulgaris L. 'Kentucky Wonder'), lima bean (P. lunatus L. 'Jackson Wonder'), and cotton (Gossypium hirsutum L. 'Deltapine 50') because previous reports indicated that $M$. phaseolina produced pycnidia on these tissues $(24,25)$.

Reisolation of $M$. phaseolina. Pieces of internal tissue 1 to $2 \mathrm{~mm}^{2}$ from margins of necrotic lesions on stems and 2 to $4 \mathrm{~mm}^{2}$ from margins in roots and crowns were excised and plated directly onto CMA. Whole pieces of leaf tissue, 2 $\mathrm{mm}^{2}$, from margins of necrosis also were plated directly onto CMA. Reisolations were attempted from four plants for each

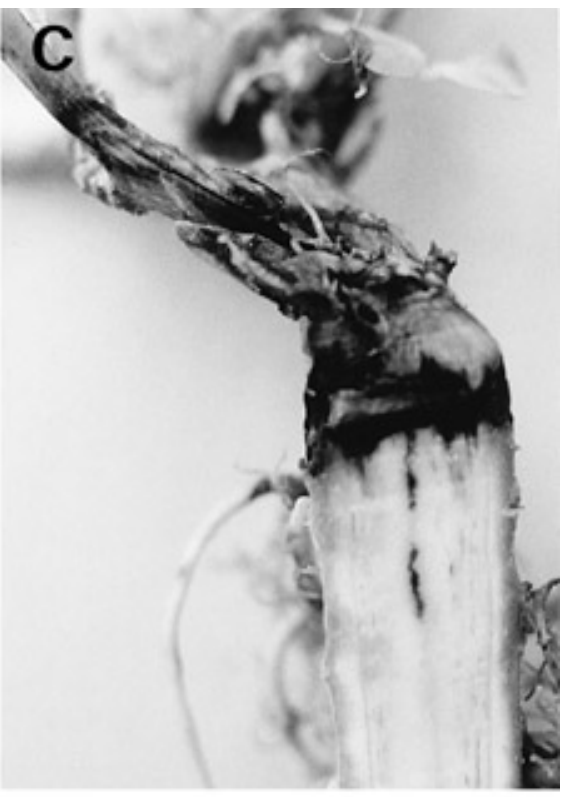

Fig. 2. Symptoms induced by Macrophomina phaseolina following inoculation of crowns and upper taproots of alfalfa. (A) Control plant with slight discoloration around wound site. $(\mathbf{B}),(\mathbf{C}),(\mathbf{D}),(\mathbf{E})$, and $(\mathbf{F})$ are inoculated plants with extensive discoloration and rotting up and down from wound sites Bisected toothpick pieces remain within plants in (B), (C), (D), and (F). Girdling or death of lower stems has occurred in (C), (D), and (E); invasion of lateral roots has occurred in (E) and (F). 
type of host tissue inoculated with each isolate.

Experimental designs and statistical analysis. Plants with inoculated stems, roots, and crowns were arranged in a randomized complete block design on a greenhouse bench with five treatments (control plus four isolates) in eight replications. Plates with leaves were arranged in trays in the same design in the growth chamber with 20 treatments (individual plant genotypes) and four replications (leaves from the same plant). Treatments were compared by analysis of variance and means were separated by the least significant difference (LSD) test at $P=0.05$.

\section{RESULTS}

Identification of $M$. phaseolina. Isolates were identified as $M$. phaseolina by production of numerous individual sclerotia throughout agar plates of CMA, and

Table 2. Mean lengths of necrosis induced in taproots of alfalfa following inoculation with isolates of Macrophomina phaseolina ${ }^{\mathrm{x}}$

\begin{tabular}{lccc}
\hline \multirow{2}{*}{ Source } & & \multicolumn{2}{c}{ Necrosis $(\mathbf{c m})^{\mathrm{y}}$} \\
\cline { 3 - 4 } & Isolates & Exp. 1 & Exp. 2 \\
\hline \multirow{3}{*}{ White clover } & 0 & $0.09 \mathrm{a}^{\mathrm{z}}$ & $0.01 \mathrm{a}$ \\
& 1 & $1.50 \mathrm{~b}$ & $0.74 \mathrm{~b}$ \\
Alfalfa & 2 & $0.46 \mathrm{a}$ & $0.32 \mathrm{ab}$ \\
& 3 & $1.22 \mathrm{~b}$ & $0.70 \mathrm{~b}$ \\
& 4 & $1.26 \mathrm{~b}$ & $2.79 \mathrm{c}$ \\
\hline
\end{tabular}

${ }^{\mathrm{x}}$ Distal ends of taproots were inoculated by inserting a small piece of infested toothpick into a puncture wound and were incubated in a greenhouse for 3 weeks. Controls (0 isolate) received noninfested toothpick pieces.

${ }^{y}$ Mean length of necrosis measured from tip of inoculation point to furthest margin of proximal necrosis in eight replicate plants arranged in a randomized complete block design.

${ }^{2}$ Means in a column not followed by the same letter differ significantly at $P=0.05$ according to the least significant difference test.

Table 3. Mean scores for disease severity in crowns of alfalfa following inoculation with isolates of Macrophomina phaseolina ${ }^{\mathrm{x}}$

\begin{tabular}{lccc}
\hline & & \multicolumn{2}{c}{ Disease severity $^{\mathrm{y}}$} \\
\cline { 3 - 4 } Source & Isolates & Exp. 1 & Exp. 2 \\
\hline \multirow{3}{*}{ White clover } & 0 & $0.25 \mathrm{a}^{\mathrm{z}}$ & $0.12 \mathrm{a}$ \\
& 1 & $1.00 \mathrm{ab}$ & $1.75 \mathrm{~b}$ \\
Alfalfa & 2 & $1.50 \mathrm{bc}$ & $1.87 \mathrm{bc}$ \\
& 3 & $2.25 \mathrm{c}$ & $2.87 \mathrm{c}$ \\
& 4 & $2.00 \mathrm{c}$ & $2.37 \mathrm{bc}$ \\
\hline
\end{tabular}

${ }^{x}$ Crowns were inoculated by inserting a small piece of infested toothpick into a puncture wound and were incubated in a greenhouse for 5 weeks. Controls ( 0 isolate) received noninfested toothpick pieces.

${ }^{\mathrm{y}}$ Mean score of disease severity, where $0=$ necrosis extending 0 to $2 \mathrm{~mm}$ from toothpick, $1=2$ to $5 \mathrm{~mm}, 2=5$ to $10 \mathrm{~mm}, 3=10$ to 15 $\mathrm{mm}$, and $4=>15 \mathrm{~mm}$, in eight replicate plants arranged in a randomized complete-block design.

${ }^{2}$ Means in a column not followed by the same letter differ significantly at $P=0.05$ according to the least significant difference test. dense masses of sclerotia on PDA that gave a black appearance to cultures. Sclerotia were irregularly spherical and within appropriate size ranges $(24,34)$. Pycnidia were never observed on agar media, but were frequent to numerous for all isolates on excised leaf tissues of bean, lima bean, and cotton $(24,25)$. The morphology of pycnidia and conidia was similar to that described previously $(33,34)$.

Stem inoculations of alfalfa and white clover. In alfalfa stems inoculated with $M$. phaseolina, dark streaks developed in vascular tissues that progressed basipetally, and parenchyma then collapsed to cause constricted lesions. In white clover stolons, similar progressive, radially constricted brown-black lesions developed, although usually without visible streaking in vascular tissue (Fig. 1). All isolates caused significant necrosis in stems of alfalfa and white clover in comparison to controls in one or both experiments (Table 1).

Root and crown inoculations of alfalfa. Control inoculations of taproots and crowns with noninfested toothpick pieces usually caused discoloration only in tissue immediately adjacent to wound sites (Figs. $1 \mathrm{~A}$ and $2 \mathrm{~A}$ ). In contrast, with toothpick pieces infested with $M$. phaseolina isolates,
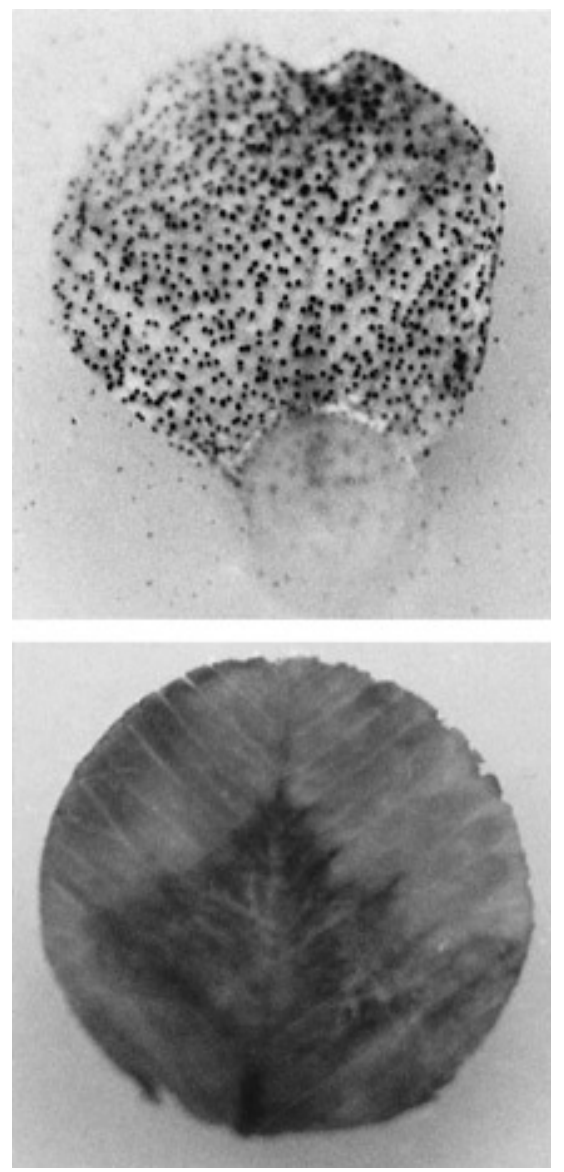

Fig. 3. Symptoms induced by Macrophomina phaseolina following inoculation of discs of leaf tissue of (top) alfalfa and (bottom) white clover with infested agar discs. Black structures in parasitized alfalfa tissue are sclerotia. red-brown to black discoloration extended up and down in vascular tissues for up to several centimeters in broad bands (Fig. 2B and $\mathrm{C}$, and $\mathrm{D}$ ) or in continuous or discontinuous streaks (Figs. 1B and C; 2D, E, and F). Cortical tissue surrounding wound sites usually was not discolored or rotted until after extensive discoloration of adjacent vascular tissues had occurred (Fig. 1B, C). With both root and crown inoculations, discoloration often extended from the vascular cylinder of the taproot into large and small lateral roots (Figs. 1B and 2E and F); sometimes the vascular system of lateral roots was completely invaded and roots were girdled and killed. From crown inoculation sites, internal vascular discoloration also extended well up into stems and often caused girdling, necrosis, and death of stems (Fig. 2C, D, and E). Pycnidia of M. phaseolina sometimes were observed on the lower surface of girdled stems.

With root inoculations, both alfalfa isolates and one white clover isolate caused greater necrosis than in controls in both experiments (Table 2). With crown inoculations, all isolates caused greater discoloration in crowns than was observed with control toothpicks in one or both experiments (Table 3 ).

Leaf inoculations. In leaf discs inoculated on agar, initial necrosis and collapse of tissue around inoculum discs were evident within 2 days. Necrosis developed distally across leaf discs in a generally even front, and most tissue was completely rotted within a week. Necrosis was manifested as a water-soaked rotting and collapse of veins and interveinal parenchyma. Invaded tissues became light green but not darkly discolored, as did stems, roots, and crowns.

Leaves of alfalfa were parasitized more rapidly than leaves of white clover (Fig. 3, Table 4). Significant differences among the 20 random alfalfa and clover genotypes were observed in both experiments with both species; however, no leaves remained free of symptoms.

Reisolation of $M$. phaseolina. Colonies of M. phaseolina developed within 2 to 3 days from pieces of diseased stem, root, crown, and leaf tissue from margins of necrosis. All isolates were reisolated from each type of tissue from both hosts and grown in pure culture.

\section{DISCUSSION}

Results of this study demonstrate that $M$. phaseolina is a pathogen of mature plant tissues of white clover and alfalfa that may incite severe symptoms of disease in the absence of other pathogens. In both hosts, it initially invaded vascular tissues and subsequently spread to adjacent parenchyma to cause complete necrosis of stems, roots, and crowns, and death of some plants. Sclerotia of $M$. phaseolina were present throughout symptomatic tissues and the fungus was reisolated consis- 
tently from margins of diseased organs of both hosts. These results fulfill Koch's postulates for M. phaseolina as a pathogen of mature plants of alfalfa and white clover for the first time in North America.

Although $M$. phaseolina has been observed on or isolated from alfalfa and white clover repeatedly in North America $(3,6,9,12,21)$, previous authors appear to have presumed its pathogenicity to both hosts and never critically evaluated this presumption on mature plant tissues. In one study, M. phaseolina was shown to cause damping-off of newly germinated seedlings of white clover in test tube culture (15). However, demonstration of a potential for damping-off of newly germinated seedlings does not constitute proof of pathogenicity of an organism to mature plants or indicate an ability to parasitize and induce symptoms in mature tissues. For alfalfa, red clover, and white clover, a wide range of fungi, including species of Alternaria, Aspergillus, Fusarium, Gliocladium, Mucor, Phoma, Pythium, and Rhizoctonia, are known to cause dampingoff of newly germinated seedlings $(8,16,17)$. However, seedlings become resistant to most of these pathogens by 5 to 14 days of age $(8,17)$; with Fusarium and Pythium spp. on alfalfa, infection of older plants then is restricted to feeder roots and does not result in clinical symptoms of disease (13). Therefore, the previously demonstrated pathogenicity of $M$. phaseolina to newly germinated seeds of white clover (15) is not considered a reliable indicator of its potential to cause disease in mature plants. For both alfalfa and white symptoms induced in mature plant tissues following artificial inoculations with $M$. phaseolina are described for the first time in this study.

The strong pathogenicity of $M$. phaseolina to mature tissues of white clover and alfalfa, as demonstrated in this study, suggests that it may limit persistence of both crops in Mississippi and elsewhere in the southeastern United States. In all experiments with stems, roots, and crowns, disease development was interrupted at 3 or 5 clover, the appearance and severity of

weeks after inoculation, but pathogenesis still appeared to be ongoing in most plants. Symptom development proceeded more slowly in some plants than in others but seldom appeared to be arrested. If similar infection of stems, roots, or crowns occurred naturally in the field in early to midsummer, then death of plants might occur by late summer or early fall. The frequent occurrence of other pathogens in infected plants in the field $(1,6,9,11,12,21)$ provides ample opportunities for pathogenic interactions with $M$. phaseolina and development of possible disease complexes $(11,18)$ that might hasten death of plants.

High temperatures, drought, and the presence of mature plant tissue are often considered necessary for complete symptom development and death of plants infected by $M$. phaseolina $(4,22,34)$. In most areas of the southeastern United States, where alfalfa and white clover are planted in the fall, all of these conditions are fulfilled by mid- to late summer of the following year. However, since high temperatures and drought did not occur in experiments during this study, the observed rates of symptom development in inoculated plants may have been lower than would occur in the field under late-summer conditions. In a second experiment with inoculated stems of alfalfa, conducted in early summer with warm temperatures and long day-lengths, necrosis of stems proceeded much more rapidly than in a previous experiment conducted in late winter (Table 1).

No information is available on disease cycles of $M$. phaseolina on white clover and alfalfa beyond its known summertime occurrence. Since numerous sclerotia are formed in parasitized tissues, there is every reason to suppose that these survive in soil and initiate infection in roots as in other hosts $(26,29,34)$.

Following inoculation of excised leaf tissues of alfalfa and white clover with $M$. phaseolina, significant differences in rates of symptom development were observed between individual plant genotypes in both species (Table 4). These differences indicated that leaf tissues of some plants were

Table 4. Mean scores of disease severity in excised leaf tissues of 20 randomly selected genotypes of alfalfa and white clover following inoculation with Macrophomina phaseolina and probabilities for differences between genotypes ${ }^{\mathrm{x}}$

\begin{tabular}{lcccc}
\hline Plant species & Exp. & Range for 20 genotypes $^{\mathbf{y}}$ & $\boldsymbol{F}$ value $^{\mathbf{z}}$ & $\boldsymbol{P}>\boldsymbol{F}$ \\
\hline White clover & 1 & $0.29-3.25$ & 3.95 & $<0.01$ \\
\multirow{2}{*}{ Alfalfa } & 2 & $0.25-2.75$ & 2.71 & $<0.01$ \\
& 1 & $1.96-5.25$ & 1.86 & $<0.01$ \\
& 2 & $3.25-5.75$ & 3.96 & $<0.01$ \\
\hline
\end{tabular}

${ }^{\mathrm{x}}$ Discs (12-mm diameter) were cut from young leaves from growing stem tips, placed individually in small Petri plates of water agar, inoculated at the base of the midvein with agar discs (4-mm diameter) infested with M. phaseolina, and incubated for 1 week in a growth chamber at $25^{\circ} \mathrm{C}$.

$\mathrm{y}$ Each value is the mean score of four leaves from each plant arranged in a randomized complete block design. Score $0=$ no symptoms of necrosis, $1=$ complete necrosis at 7 days after inoculation, $2=$ necrosis at 6 days, $3=$ necrosis at 5 days, $4=$ necrosis at 4 days, $5=$ necrosis at 3 days, and $6=$ complete necrosis at 2 days. Leaf discs not completely necrotic at 7 days after inoculation were scored according to the proportion of tissue estimated to be necrotic.

${ }^{\mathrm{z}} \mathrm{F}$ value for genotype differences. less susceptible to $M$. phaseolina than leaf tissues of others. Relationships of leaftissue responses to root, crown, and stem responses of different genotypes following inoculation with $M$. phaseolina are not yet known for alfalfa or white clover. If positive relationships are found, then possibly leaf-disc inoculations could be used to screen for host resistance to M. phaseolina as with Sclerotinia trifoliorum on alfalfa (28). The fact that specific genes for resistance to $M$. phaseolina have been demonstrated in several other crops recently $(10,23,30,32)$ lends support to the idea that such genes also may be present in alfalfa and white clover.

\section{LITERATURE CITED}

1. Albrecht, H. R. 1942. Effect of diseases upon survival of white clover, Trifolium repens L., in Alabama. J. Am. Soc. Agron. 34:725-730.

2. Anderson, B., and White, D. G. 1987. Fungi associated with cornstalks in Illinois in 1982 and 1983. Plant Dis. 71:135-137.

3. Boewe, G. H. 1963. Host plants of charcoal rot disease in Illinois. Plant Dis. Rep. 47:753755.

4. Edmunds, L. K. 1964. Combined relation of plant maturity, temperature, and soil moisture to charcoal stalk rot development in grain sorghum. Phytopathology 54:514-517.

5. Farr, D. F., Bills, G. F., Chamuris, G. P., and Rossman, A. Y. 1989. Fungi on plants and plant products in the United States. American Phytopathological Society, St. Paul, MN.

6. Garren, K. H. 1955. Disease development and seasonal successions of pathogens on white clover. Part II-stolon diseases and the damage-growth cycle. Plant Dis. Rep. 39:339-341.

7. Gibson, P. B., and Cope, W. A. 1986. White clover. Pages 471-490 in: Clover Science and Technology. N. L. Taylor, ed. Am. Soc. Agron., Madison, WI.

8. Grau, C. R. 1990. Pythium seed rot, dampingoff, and root rot. Pages 11-12 in: Compendium of Alfalfa Diseases. 2nd ed. D. L. Stuteville and D. C. Erwin, eds. American Phytopathological Society, St. Paul, MN.

9. Gray, F. A., Haaland, R. L., Clark, E. M., and Ball, D. M. 1980. Diseases of alfalfa in Alabama. Plant Dis. 64:1015-1017.

10. Grezes-Besset, B., Lucante, N., Kelechian, V., Dargent, R., and Miller, H. 1996. Evaluation of castor bean resistance to sclerotial wilt disease caused by Macrophomina phaseolina. Plant Dis. 80:842-846.

11. Halpin, J. E., Gibson, P. B., Beinhart, G., and Hollowell, E. A. 1963. Selection and evaluation of white clover clones. II. The role of midsummer diseases. Crop Sci. 3:87-89.

12. Halpin, J. E., and McCarter, S. M. 1961. Fungi associated with white clover stolons in selected areas of the Southeast during midsummer, 1959. Plant Dis. Rep. 45:298-299.

13. Hancock, J. G. 1985. Fungal infection of feeder roots of alfalfa. Phytopathology 75:1112-1120.

14. Kadlicsko, S. 1994. Some new results on the host range of Macrophomina phaseolina in Hungary. Acta Phytopathol. Entomol. Hung. 29:61-66.

15. Kilpatrick, R. A. 1959. Fungi associated with red and white clovers in New Hampshire. Plant Dis. Rep. 43:1111-1113.

16. Kilpatrick, R. A., Hanson, E. W., and Dickson, J. G. 1954. Relative pathogenicity of fungi associated with root rots of red clover in Wisconsin. Phytopathology 64:292-297.

17. Leath, K. T. 1985. General diseases. Pages 205-233 in: Clover Science and Technology. 
N. L. Taylor, ed. Am. Soc. Agron., Inc. Madison, WI.

18. Leath, K. T. 1990. Crown and root rot complexes. Pages 43-44 in: Compendium of Alfalfa Diseases. 2nd ed. D. L. Stuteville and D. C. Erwin, eds. American Phytopathological Society, St. Paul, MN

19. McCarter, S. M., and Halpin, J. E. 1962. Effects of four temperatures on the pathogenicity of nine species of fungi on white clover. (Abstr.) Phytopathology 52:20.

20. McDonald, D., and Mehan, V. K. 1984. Charcoal rot. Pages 27-28 in: Compendium of Peanut Diseases. D. M. Porter, D. H. Smith, and R. Rodriguez-Kabana, eds. American Phytopathological Society, St. Paul, MN.

21. McGlohon, N. E. 1959. Survey of fungi associated with white clover stolons. Plant Dis. Rep. 43:22-24

22. Odvody, G. N., and Dunkle, L. D. 1979 Charcoal stalk rot of sorghum: effect of environment on host-parasite relations. Phytopathology 69:250-254.

23. Olaya, G., Abawi, G. S., and Weeden, N. F. 1996. Inheritance of the resistance to Macro- phomina phaseolina and identification of RAPD parkers linked to the resistance genes in beans. Phytopathology 86:674-679.

24. Ostazeski, S. A. 1964. Sporulation of Leptodiscus terrestris on propylene oxide sterilized culture media and a technique for differentiating some sclerotial fungi. Plant Dis. Rep. 48:770-771.

25. Ostazeski, S. A. 1967. An undescribed fungus associated with a root and crown rot of birdsfoot trefoil (Lotus corniculatus). Mycologia 59:970-975.

26. Pande, S. 1986. Charcoal Rot. Pages 29-30 in: Compendium of Sorghum Diseases. R. A. Frederiksen, ed. American Phytopathological Society, St. Paul, MN.

27. Pederson, G. P., and Pratt, R. G. 1995. Differential summer survival of white clover stolons: germplasm and fungicide effects. Crop Sci. 35:1282-1287.

28. Pratt, R. G. 1996. Screening for resistance to Sclerotinia trifoliorum in alfalfa by inoculation of excised leaf tissue. Phytopathology 86:923-928.

29. Short, G. E., Wyllie, T. D, and Bristow, P. R.
1980. Survival of Macrophomina phaseolina in soil and in residue of soybean. Phytopathology 70:13-17.

30. Smith, G. S., and Carvil, O. N. 1997. Field screening of commercial and experimental soybean cultivars for their reaction to Macro phomina phaseolina. Plant Dis. 81:363-368.

31. Stuteville, D. L., and Erwin, D. C. 1990 Other fungi associated with alfalfa. Page 45 in: Compendium of Alfalfa Diseases. 2nd ed. D. L. Stuteville and D. C. Erwin, eds. American Phytopathological Society, St. Paul, MN.

32. Tenkouano, A., Miller, F. R., Frederiksen, R. A., and Rosenow, D. T. 1993. Genetics of nonsenescense and charcoal rot resistance in sorghum. Theor. Appl. Genet. 85:644-648

33. Watanabe, T. 1972. Pycnidium formation by fifty different isolates of Macrophomina phaseoli originated from soil or kidney bean seed. Ann. Phytopathol. Soc. Jpn. 38:106-110.

34. Wyllie, T. D. 1989. Charcoal Rot. Pages 3033 in: Compendium of Soybean Diseases. 3rd ed. J. B. Sinclair and P. A. Backman, eds. American Phytopathological Society, St. Paul, MN. 